\title{
Roads to complexity: Hawaiians and Vikings compared
}

\author{
Mads Ravn (1D ${ }^{\mathrm{a}, \mathrm{b}}$

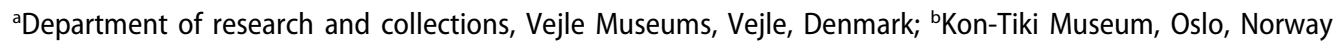

\begin{abstract}
The purpose of this paper is to analyse roads to complexity and societal development. By comparing the processes leading to complexity in Late Iron Age and early Viking society in South Scandinavia with the pre-contact Hawaiian state, I set the framework for a comparative archaeology and suggest that society in the Viking Age was not a state. I reach this conclusion within a comparative framework, by looking at comparable but also different processes in both places over time between the subject and source, in Scandinavia and Hawaii. I estimate how important geographic, cultural, technological, ideological, and ecological factors were for the development and change in both places in general and for the advent of the complexity in particular. I suggest that the analogical approach gives us a less biased perspective in both places, because we avoid partial metanarratives, such as for example teleological, nationalist narratives. Using this approach, we will discover new aspects that cannot be identified in isolation.
\end{abstract}

\section{ARTICLE HISTORY}

Received 21 December 2017

Accepted 19 April 2018

\section{KEYWORDS}

Comparative archaeology; analogies; Vikings; Hawaiian states; complex societies

\section{Introduction}

Comparisons between contemporary societies studied by anthropologists and prehistoric societies studied by archaeologists, the so-called analogies, have long been used (Wylie 1985, Ravn 1993, for an overview). While many such comparisons have been called hypotheses or theories, this makes them no less subject to the logic of analogical reasoning (Wylie 1982, Ravn 2011). But the archaeological data have not always been able to 'answer' correctly the convincing models developed from analogy. According to Spriggs:

'Ever-more Pacific-looking European pasts are being constructed by European... archaeologists. Melanesian anthropology is being continuously mined for supposed ethnographic parallels to elucidate the European Neolithic with its "Big Man" societies... And the Bronze Age of Europe and the Levant is also looking increasingly suspiciously like a series of Polynesian chiefdoms minus the coconut trees and the surf and transported to less balmy climes' (Spriggs 2008, p. 538-39).

The main criticism from researchers of the Pacific (Roscoe 2009, Ravn 2011) is that European archaeologists have seen only 'snapshots' of a society where the population, and thus the social organisations have often been affected by new, decimating diseases after contact with Europeans. Following Spriggs:
What I find most remarkable about this Melanesian and Polynesian turn in European prehistory is that, although it is fuelled by a detailed poring over the detail of Pacific and other Third and Fourth World ethnographies, it manages to ignore totally the results of the archaeology of these ethnography-rich regions (Spriggs 2008, p. 539).

In other words, the uses of those analogies have not included the longue durée, (Braudel 1980) of the societies compared. Because I suggest that analogies are useful for applying a more balanced comparative archaeology, modelling the roads to complexity, we need to briefly discuss the definition of analogy.

\section{The definition of analogy and its recent use}

The comparisons presented above are, according to Wylie, formal analogies. They have been based on simple: 'point for point assessment of similarities or differences in the properties of source and subject' (Wylie 1985, p. 94). Unlike a relational analogy that is: 'a function of knowledge about underlying "principles of connection" that structure source and subject and that assure, on that basis, the existence of specific further similarities between them' (Wylie 1985, p. 95). 
The lack of awareness of the definition of relational analogies has made archaeologists cautious, especially because analogies contain an element of subjectivity. Positivist and post-positivist archaeologists especially, were, and to a certain degree still are, sceptical to analogies (Kristiansen 2017, Sørensen 2017), although they also are used in many other positivist-oriented disciplines, including the natural sciences. The scientific philosopher Susan Sterrett stresses, for example, Ernst Mach, who developed the analogy that both light and sound are waves. This is based on the Doppler Effect, assuming that the same laws applied to sound as to light (Sterrett 1998,2017 , p. 866). Based on this analogy, one is able to calculate the size of the universe and find out that it expands. Stephen Hawking also used analogical reasoning for understanding how black holes emit very little light, the so-called Hawking radiation (Hawking 1974, see also Visser 2003), the assumption being that waves work in the same way everywhere in the universe (Rousseaux 2013).

The simplistic definition of analogy and the phenomenon of equifinality (Ravn 2011): that vastly different behaviour patterns can lead to the same material patterning has also been seen as problematic. With the advent of numerous multi-proxy methods that are applied in manifold ways on 'bigger' data, this phenomenon, although still present, has waned (Grabowski 2014).

Regarding the definition, if analogy is defined as: 'the selective transposition of information from source to subject on the basis of a comparison that, fully developed, specifies how the terms are compared to similar, different, or of unknown likeness' (Wylie 1985, p. 93), the concept is less controversial because it involves understanding the processes behind the similarities and differences. Only multiple lines of circumstantial evidence can substantiate the strength of the analogue and make it a stronger 'cable' (Wylie 1989, Sterrett 2017, p. 870).

\section{Analogical cables with a longue durée on both the source and the subject side}

The way forward with the use of analogies in archaeology is to compare the longue durée at both the source and subject side of the analogy, as emphasised recently (Spriggs 2008). In this way, we may better assess different historical, cultural and ecological trajectories and reasons for various phenomena over time and understand whether they mattered in this particular process or region. We not only learn more about the culture we compare (the subject side of the analogy). We also improve our knowledge of the culture that we use as a source of comparison (the source side of the analogy). This may involve the use of ethno-archaeology, which links material culture behaviour patterns of the present with material culture behaviour patterns of the past (Ravn 1993, p. 74). Other times we may use analyses of the archaeological material and written sources in a protohistoric society and compare them with the archaeology of a prehistoric society. This is called historical analogy (Ravn 2003, p. 2). Against this background, we can map more solid variables and constants and better understand how they diverge under given circumstances in a society, be they religious, social, cultural, ecological, geographic or climatic.

\section{Competition and bottlenecks: early roads to complexity in a comparative perspective}

Before moving on to the discussion of roads to complexity, I need to briefly present the term 'bottlenecks'. Earle and Spriggs (2015) have, in a comparative perspective, defined bottlenecks as: 'constriction points in commodity chains that offer an aspiring leader the opportunity to limit access, thus creating ownership over resources, technologies or knowledge' (Earle and Spriggs 2015, p. 517). They suggest (Earle and Spriggs 2015, Spriggs et al. 2016) that Neolithic economies and early Hawaiian culture in Oceania had economic and geographical settings that were too open for chiefs to monopolise resources and land. Thus, they could not create bottlenecks. On that basis, they conclude that few Neolithic societies developed into complex societies. A prestige goods economy does not emerge before the Bronze Age in Europe and in late precontact Neolithic Oceania, especially in Hawaii (Earle and Spriggs 2015, p. 522).

\section{Roads to complexity in chiefdoms and kingdoms: bronze, iron and Viking Age South Scandinavia and early states in Hawaii}

In terms of the longue durée, Kristian Kristiansen (2016) has compared the Bronze Age of Scandinavia (ca. 1500-1100 BC) with the Viking Age, concluding that: '.the Viking Age of Northern Europe shares many of the features we now associate with the Bronze Age'.. 
in terms of structure,.. 'but the Viking Age was apparently able to expand on a larger geographical scale due to technological and demographic developments since the Bronze Age' (Kristiansen 2016, p. 181).

Suggesting that Scandinavian Bronze Age and Viking Age societies represent a 'structural "longue durée" based on similar structural foundations', Kristiansen (2016, p. 178) outlined several similarities in both the Bronze Age and Viking Age. Important are symbolic similarities: burial mounds, strong warrior ethos, expressed with chiefly and functional warrior swords. In addition, both periods share the expressive use of symbolic decoration and decorative style with cosmological meaning. In terms of communication and transport, ship burials and seafaring are dominant ways of communication in both periods. Indeed, Glørstad and Melheim (2016, p. 100) drew comparison between seafaring in the Viking Age, the Bronze Age and the rise of the Hellenic power during the Peloponnesian wars in the fifth century BC. Economically, in both periods, we find individual farmsteads, which function as the basic economic unit, though in the Iron and Viking Age, there are also villages. Exchange is dominant, although in the Viking Age, the emphasis is increasingly on commercial ports of trade. In both periods, we see a decentralised political economy. Socially, in both periods, society consisted of free farmers who are represented as the dominant warrior class. Ritually, in both periods, we observe that there are ritual meeting places and hoarding of metal valuables in the landscape.

An important difference between Bronze Age and Viking Age society that Kristiansen stresses is a missing social/political level above the chiefly families of free farmers, traders, and warriors in the Northern Bronze Age. That level is the king or paramount and his ability to recruit a proportionally larger military force through vassal chiefs.

Hawaii offers a stronger, structural 'cable' (Wylie 1989), especially if we want to understand the roads to early kingdoms in the Germanic Iron Age and Viking Age South Scandinavia, because paramount chiefs are present in both places. Additionally, comparing two independent societies, separated in both time and space, which ended up with a similar, though not an identical kind of complexity will lead to a better explanation, as it requires a more detailed understanding of the prerequisites for the development of these societies.
With the structural longue durée, in South Scandinavia emphasised by Kristiansen (2016, p. 178 ) in mind, this approach differs from traditional neo-evolutionary perspectives, which typically look for normative societal types (Drennan et al. 2012, p. 2, Smith and Peregrine 2012, Feinman 2012), disregarding dissimilarities and the longue durée, as Spriggs points out above (2008). The analogical approach advocated for here on the other hand, stresses a stronger, processual, 'cabled' (Wylie 1989) and diachronic perspective, equally comparing both sides of the analogical 'equation', using similarities and differences as navigation points of reference. Following Wylie: '..., the model may be a conceptualisation of a context...that is substantially unlike any single accessible... analogy.' (Wylie 1985, p.106).

\section{Hawaiian society}

The chiefdom of the paramount of Kalaniopu'u, which James Cook encountered in 1779 in Kelakekua Bay in Hawaii (Beaglehole 1967, p. 490, Kirch 2000b, p. 248), numbered at least 60,000 maybe even up to 150,000 people and was one of the most complex communities throughout Oceania (Earle and Spriggs 2015, p. 525) (Figure 1).

Anthropologists have called Hawaiian pre-contact society an advanced chiefdom or even a state. Archaeological research has confirmed this contention (Kirch 2000a, b, Earle and Spriggs 2015). Indeed, Hommon (2013, p. 121) defined a state as a:

durable, large-scale, territorially-based, autonomous society in which a centralized government, directed by a leader or group of leaders, employs legitimate political power, backed by coercion, to exercise sovereignty

Furthermore:

...the leader or leading group, usually of a ruling class, makes decisions regarding - and delegates power to a stratified bureaucracy charged with implementing certain society-wide tasks, including the colleting of taxes, the conduct of state rituals, the promulgation and enforcement of laws, the development of public works, the maintenance of intrapolity order, and the management of extrapolity relations by means of trade, diplomacy, and war.

This state developed from a few colonising boats that came from possibly Tahiti in East Polynesia ca. 


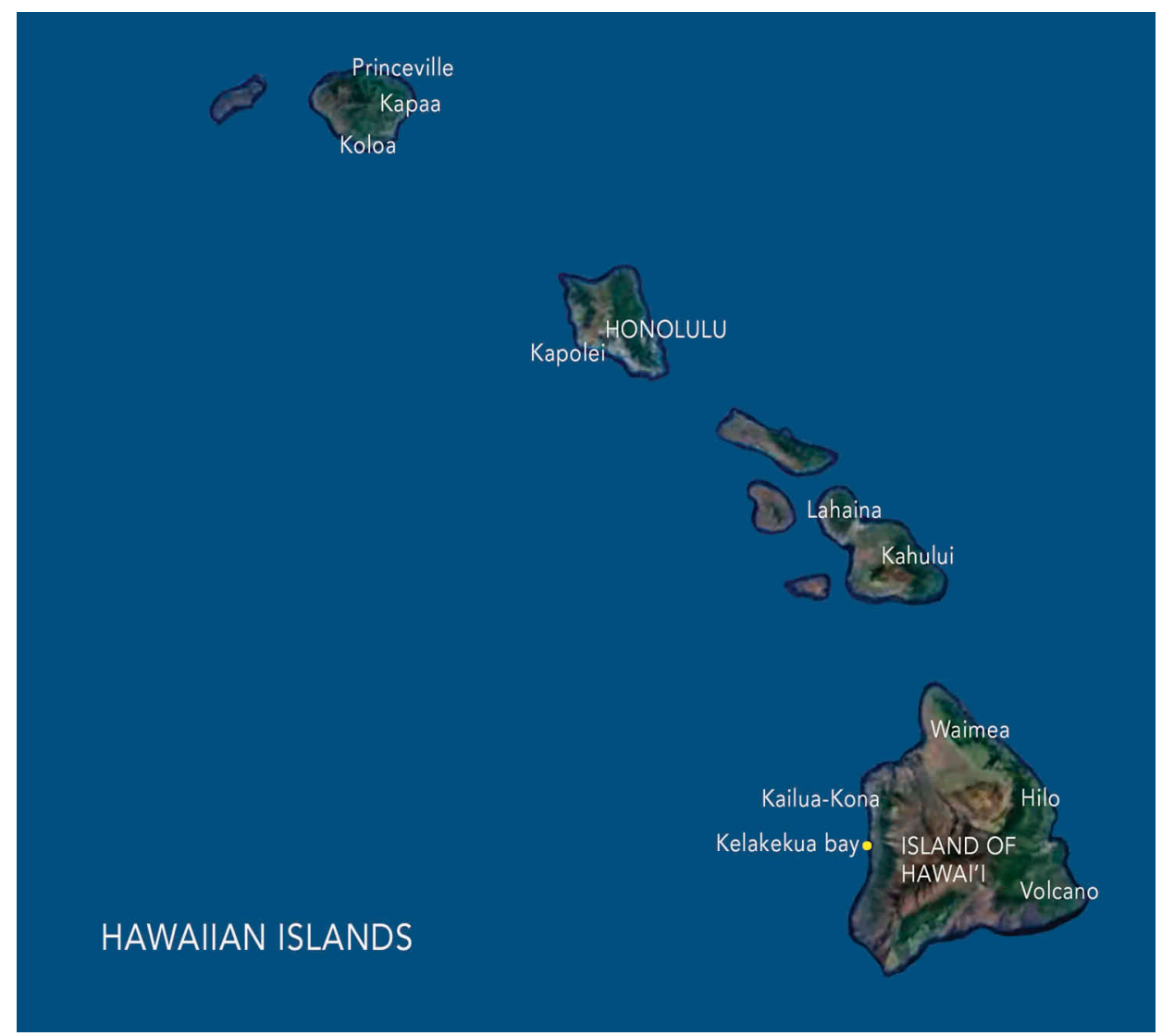

Figure 1. Overview of the Hawaiian Islands. The yellow spot marks the area where James Cook landed in 1778 and 1779 (Graphics: VejleMuseerne).

$4000 \mathrm{~km}$ to the south around AD 1000 (Hommon 2013). Important here is that Hawaiian society, unlike the Germanic Iron Age and Viking Age kingdoms of Scandinavia, developed over hundreds of years into a very stratified society in isolation from external pressure and external contacts, neither from a German-Roman emperor, nor by monopolising exotic, long-distance trade objects (Ravn 2003). In other words, there was no centre-periphery relations in Hawaii, a relation that otherwise has been stressed as important in the formation of early states (Wallerstein 1974, Champion 2005).

\section{Population growth}

Apparently, the population of Hawaii was allowed to grow rapidly, probably due to the lack of malaria and other common infectious diseases in this area of the Pacific (Sand 2002). The geologically older islands of O'ahu and Kaua'i, with their ample water supply, became covered with irrigated pond fields for taro, fishponds and tree grooves of bananas, breadfruit and coconut as well as religious monuments, roads and field walls (Figure 2). All this attests to an intensified use of resources over time, and an increasing population, especially from AD 1200. The younger islands of Maui and Hawaii $i$ to the east had dry fields that were used for growing sweet potato and raising the pigs that were prestigious ceremonial offerings and gift payments. In time, chiefs came to control the most productive stapleproducing lands and, following Earle and Spriggs. 'The ancient lineage system through which commoners claimed rights to the land was supplanted by a feudallike system in which commoners gave obligated labor and material in return for access' (Earle and Spriggs 2015, p. 525; see also Hommon 2013, p. 18). A tribute system was introduced (ahupua'a) with overarching ownership vested in the paramount chief. The close kin of the paramount received units of fiefs and the commoners received subsistence plots. On the islands of O'ahu and Kaua'i especially, chiefs divided subsistence plots among farmers under a manager's oversight. The farmers were obliged to work the chief s plots and fishponds, generating surplus to support the chief. 


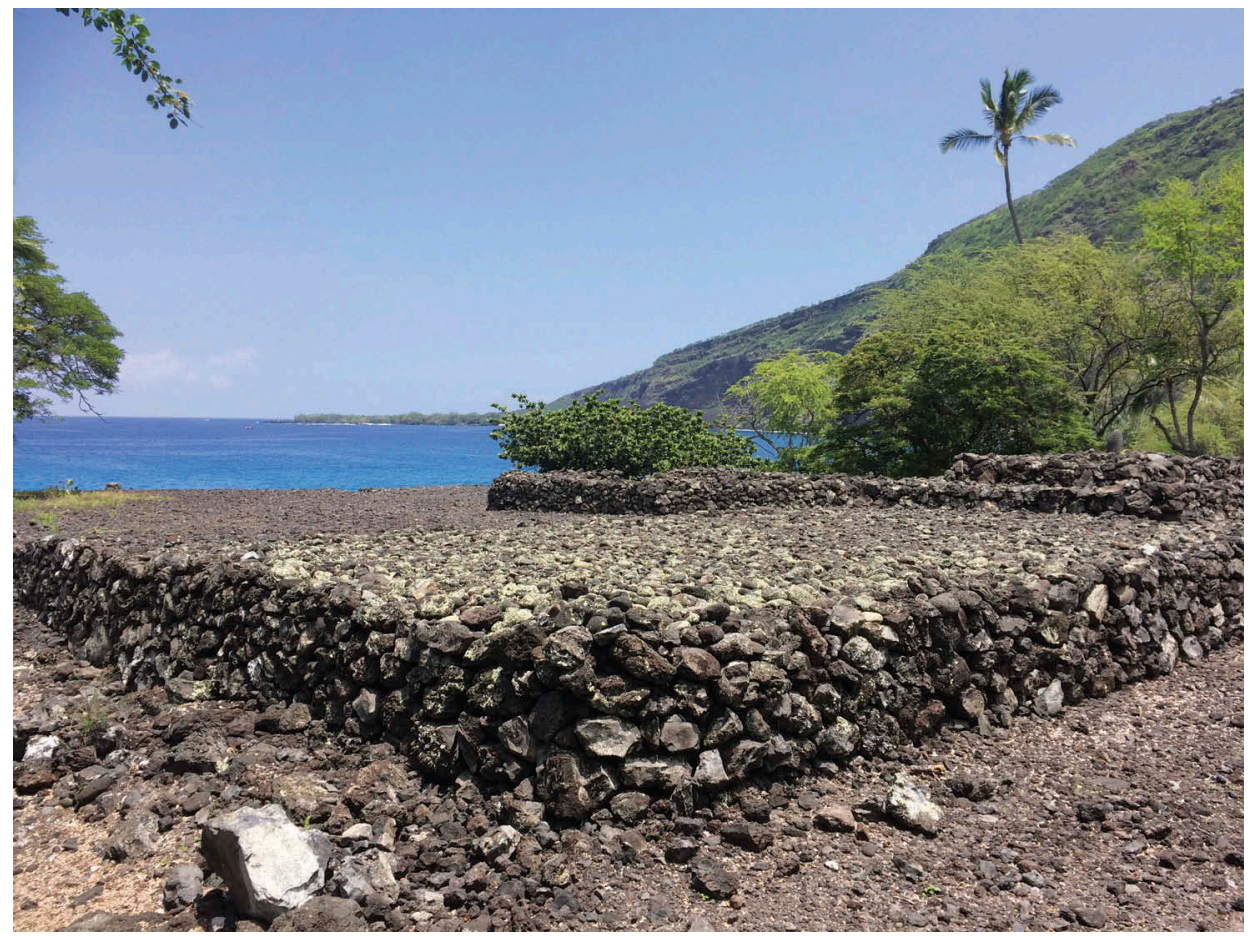

Figure 2. When James Cook on his third sea voyage arrived in 1779 with his majesty's ships resolution and discovery in Oceania at Kealakekua Bay, about 3000 canoes escorted him. Here is a view from a sacred platform. In the background, we see Kealakekua Bay (Photo: Mads Ravn).

\section{A bottleneck}

There is here a good example of a bottleneck, as defined by Earle and Spriggs (2015, p. 517). In addition, the extensive terraces that according to Ladefoged and Graves (2006, p. 280) were subdivided over time into smaller units suggest that there was a concept of property rights and increasing pressure on land. Patterns of the intensification of agricultural production makes Hommon suggest a hard times hypothesis, where chiefs redefined their roles towards more concentration of power in fewer hands in hard times (Hommon 2013, p. 235). In effect, one paramount king (Hommon 2013, p. 258) slowly replaced a diarchy.

The stratified polities of Hawaii, however, could not grow by compiling surplus for the chiefs alone. Wars against and conquest of other polities increased - a process that depended on warriors and priestly specialists. This process between peer islands can be seen as an ideal example of a peer-polity interaction (Renfrew and Cherry 1986). Internal war also helped to formulate an ideology that emphasised external kings with an exotic background, so-called 'stranger kings', being external to the linage. Unlike family relations they could better suppress their subjects, additionally claiming that they were linked to divine powers (Sahlins 1985). In concert, the development supported by surplus production broke local community ownership rights, thus creating an overarching power for the paramount chief and a new institutional order based on warriors and a priestly class.

\section{Strong aristocracy}

In order to institutionalise the regional Hawaiian chiefdoms, social labour was mobilised by chiefs. They raised a hierarchy of temples that marked the landscape and obliged communities to support annual ceremonies. The eventual creation of a divine kingship was dependent on ceremonies, supported by surpluses from the extensive irrigation systems. By the end of the process, a smaller but distinctive class of rulers appeared who asserted ownership over community lands, their facilities and staple production. Following this, an increasing bureaucracy of specialists involved in land management, warrior might, and religious sanctification was established. 


\section{Prestige goods}

Hawaiian prestige items included feathered cloaks, helmets, and elaborately carved idols and bowls. In addition, an important part of the chiefly and religious material culture was special woven mats, elaborately decorated tapa cloth, weapons and basalt adzes. In contrast to Northern Europe, suitable raw materials were widely available, so it was more the artistry of the highly skilled specialists that made the objects prestigious. These objects were not a part of a large network of long-distance trade. The objects functioned as an extension of staple finance, and the chief received them in an annual collection. The chief's household supported artisans who transformed these materials into symbolic objects and received land in return for their skilled labour.

Feathered cloaks for the paramount chief were distributed to supporting chiefs. These special goods became props in the ceremonies and the dress of high chiefs as god kings. In addition, warrior canoes helped solidify control over the warriors, who were so important for conquest. Although canoes thus were necessary for their ancestors, who arrived on the shores around $\mathrm{AD} 1000$, long-distance voyaging with sails diminished in importance.

\section{Social structure}

Just before European contact, there were specialised farmers, fishermen, craftsmen, warriors and priests, chiefs and paramount chiefs and a delegated bureaucracy. The chiefs (Ali $i$ ) were masters of tens of thousands of people and were both leaders of the local clan or tribe, and descended directly from the gods. Within the chief group, there were eight subdivisions of up to eight groups. In the end, the paramount chief might marry a sibling to concentrate the bloodline. Chiefs drafted large-scale labour in order to build temples and irrigation channels, but few impressive monuments apart from temples (Heiau) and no nucleated villages or towns ever developed (Hommon 2013, p. 260). Tribute consisted of food for the chieftain's household. The common people did not have the right to land, but paid tributes to those whose land they cultivated. Anthropologist Marshall Sahlins (1958) and Irving Goldman (1970) classified the Polynesian chiefdoms into three types, where Type I, of which Hawaii is an example, was the most stratified.

\section{The Viking analogy}

The Scandinavian Viking Age (traditionally dated to 793-1050 AD) is a period that due to a nationalist revival in the nineteenth century, has become legendary. I suggest, however, that one is able to find most of the conditions and defining points for the Viking Age in the preceding Roman and Germanic Iron Ages ca. AD 200-800 (Ravn 2003). Extensive seafaring, new boat technology, long-distance exchange, raids in Northern Europe, concentration of power, warrior ideology, socially stratified graves, wars, migrations, ethnogenesis, the development of emporia and formation of kingdoms, all these phenomena were already well under way before the start of the Viking Age proper. Therefore, the Viking Age, in my view, is arbitrarily defined and needs to be extended back in time. This is especially the case when one looks at the development of complexity and concentration of power in this region in a much longer time perspective than many Viking scholars traditionally have done (see also Näsman 2006). I call this analogical subject of investigation the 'Viking analogy', although I extend it further back in time than the usual definition allows.

\section{Sources revealing complexity}

It is difficult to measure the degree of stratification within Europe and especially Scandinavia. At this time, Scandinavia was prehistoric, and in many cases, we encounter less source material than from the period of Hawaiian state development. Foreign missionaries and Merovingian, Carolingian and Anglo-Saxon chroniclers are the main sources for the early Danish kingdoms. Thus, it is only by comparing South Scandinavia, where the sources are mainly archaeological, with the rest of Europe, where written accounts and archaeology reveal varying stratified societies according to region, that we may reach an understanding of how and when the formation of stratified kingdoms and complexity of South Scandinavia occurred.

Chris Wickham has discussed the challenges of grasping this complex period, indeed emphasising a comparative approach:

Historians who study one society alone, never looking at others, lack an essential control mechanism, and not 
only risk misunderstanding, of what are real causal elements or turning-points and what are not, but also are in danger of falling into metanarratives of national identity, the teleologies of what makes Us special, which bedevil the historical enterprise (Wickham 2005, p. 825).

Additionally, his overview of this vast and complex area of Europe, understanding some of the major differences and similarities on a structural basis is interesting. With a quite similar materialist approach to Earle and Spriggs (2015) and Hommon (2013) for Hawaiian society, Wickham defines a number of economic aspects that characterise this diverse period. Here I shall focus on South Scandinavia, the region later to become the kingdom of Denmark.

\section{Roman collapse leads to a weak aristocracy}

From the fifth century, according to Wickham, we see a collapse of fiscal structures in the Roman Empire, which leaves the majority of Europe with a relatively weak aristocracy. This is also true of South Scandinavia, which is characterised by a decentralised political system and a number of regional kingdoms until the eighth, or perhaps the tenth century (Wickham 2005, p. 371). Numerous finds of imported glass and metal bowls, as well as coins produced in the late Roman provinces support the interpretation that a prestige economy was well underway already in the first half of the first millennium. Graves attesting to some level of regional hierarchy indicate that it was a ranked prestige, and not a monetary, economy (Hedeager 1992, Ravn 2003). Also, the relative homogeneity of villages points to a peasantry that recognises a leader, not a landlord. In the Western Roman Empire, as the economy partly collapses in the fifth century, a number of Germanic migrations across Europe make it a period of instability. In the written sources, tribes numbering as many as 100.000 appear. The first mention of a tribe known as the Danes appears in the works of Gregory of Tours, who describes a sixth century raid on Paris by the kings of the Danes (Gregory of Tours 1974, III: 2).

\section{Archaeological evidence for social complexity}

In the western part of South Scandinavia, we have a settlement pattern, consisting of small villages and hamlet communities of 3-10 farm units. People practiced a plot organisation of land, where farms were founded according to neo-locality and bilateral heritage patterns (Holst 2010). This means that the offspring of a farmer established a new farm within a predefined plot, already belonging to the family. When the parents died, the old farm was demolished, on average about every 30 years. This pattern is clearly observable in Jutland, in the western part of South Scandinavia (Holst 2010, p. 172, 2014). We also see this practice mentioned in the contemporary Germanic Lex Babarorum, further south. The subsistence pattern in South Scandinavia at this time is rural. In the western part (Jutland), we have a more scattered settlement pattern, while the magnate farms of the eastern isles and Scania indicate a higher level of coercion and a strata of retinue warriors and specialised craft persons.

\section{Magnate farms}

I shall here focus a bit more on the magnate farms in the east. In East and Central Scandinavia the occurrence of large amounts of gold, a metal not found naturally in South Scandinavia, alongside the remains of large sixth century magnate farms, suggests that gold was used as a sign of wealth in a prestige production economy guided by the magnate (Christensen 2015). The magnate farm of Lejre where, according to the epic poem Beowulf, the Danish kings ruled and the equally rich manor of Tissø (Jørgensen 2010, Christensen 2015) was the central unit that defined the social bond of the 'house' (Figure 3). Levi Strauss defined such a term a 'société À maison' or 'house society' (Gillespie 2000). It was within this house society, which ran beyond genetic relations, that social relations were organised in relation to the magnate. The sacred function was most likely connected to the king or magnate, who acted as an intermediary between the gods and the people. He was also the person who performed the rituals.

This 'eastern' organisation is apparently not as widespread in the egalitarian house structures of Jutland in western Denmark (Jessen and Holst 2008, p. 51, Holst 2014, see however Ravn et al. in prep.). Hence, a relatively egalitarian pattern based on genetic relations in the west stands in some contrast to the magnate farms that already from the sixth century appear in Sealand, Scania as well as 


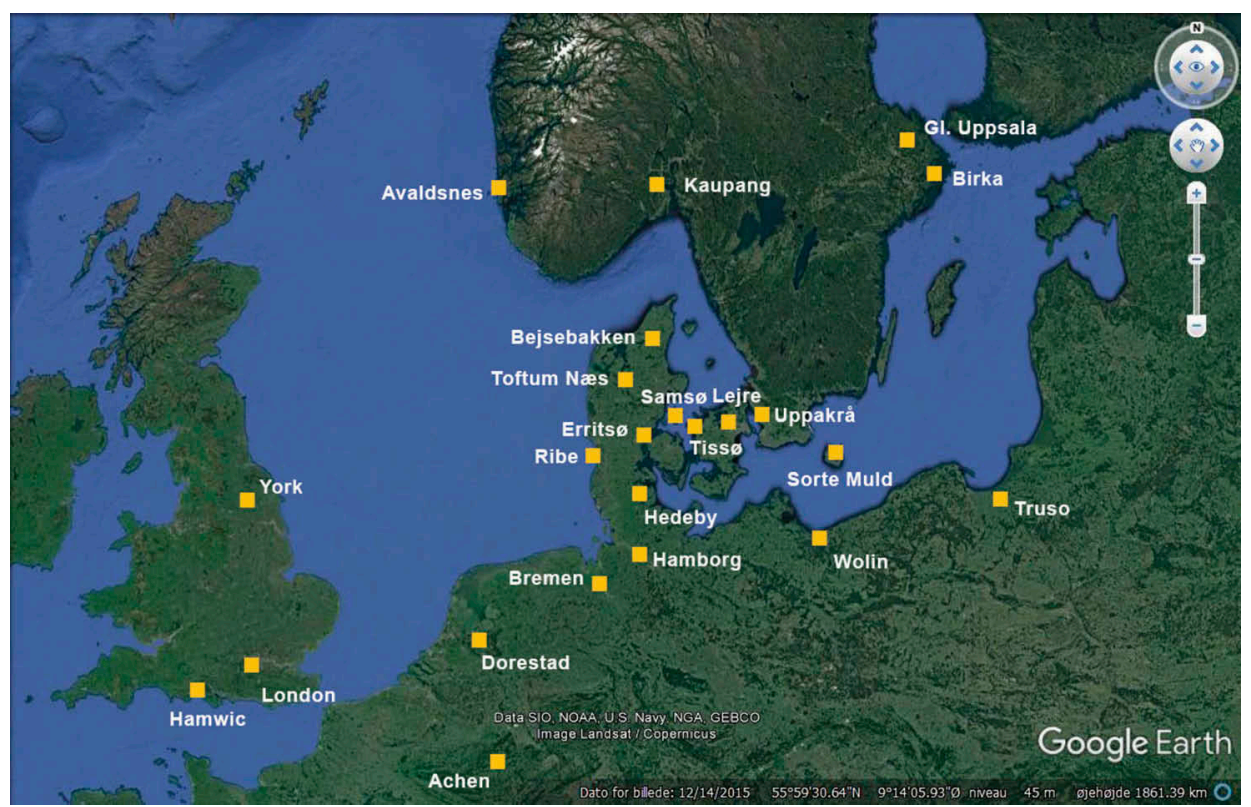

Figure 3. Overview of south and central Scandinavia with a number of important locations from the GERMANIC IRON AGE and early Viking Age. The red spot marks a recently discovered magnate farm in Jutland (graphics: Google Earth and adapted by VejleMuseerne).

in Gamla Uppsala in central Sweden (Ljungqvist and Frölund 2015). Still, Wickham suggests: 'that even in the eighth and ninth centuries, and still more in the fifth and sixth, aristocratic economic dominance over peasant neighbours was not established in Denmark'(Wickham 2005, p. 375).

It is possible that the commoners in South Scandinavia paid a kind of tribute, not tax, for protection in recognition of the suzerainty of the lord in the later phases of the Viking Age (Vogt 2017).

\section{What's in a name}

Before continuing, a brief discussion of the word 'king' will be worthwhile. The term appears in the Germanic language as far back as the fourth century, amongst the Goths (Kindins, in Latin Judex). The Goths were the first Germanic people to be admitted into the Roman Empire, in AD 376 (Ravn 2003). Kindins, in the ancient Gothic language, refers to an elected person who governs people, but who in general holds more symbolic power (Ravn 2003, p. 8). He is in contrast to a reiks, who was a warlord. This duality of power between a symbolic and executive leader is also present in Hawaii prior to the concentration of power and the emergence of the Hawaiian state in the seventeenth and eighteenth centuries. We also see elements of this when the Viking king Hemming dies in AD 812. He was succeeded by kings, Harald and Reginfred. The pattern of dual kings continued throughout the ninth century.

A kindins had the juridical ability to judge someone, hence the word kingdom (i.e. a king who judges, in Danish a 'dommer' is a judge), whereas the reiks among the Goths were only given power in times of war. In that sense, the presence of the word king does not, in itself, indicate a centralised and stratified state governing a major area of land with a bureaucracy (Näsman 2006). In Scandinavia, we do not see that before possibly the tenth century (Wickham 2005, p. 379), or maybe even later (Bagge 1999).

\section{Towards an explanation of complexity in Viking Age and Hawaiian society}

The comparisons so far have been descriptive. In order to reach a deeper understanding of the common drivers of complexity, the first step is to outline the similarities and differences between both places (see Table 1).

\section{Similarities}

In terms of social structure, both had decentralised individual farmsteads and villages. Initially free farmers represent the dominant warrior class. Over time, a layer of retinues and supervisors, in the Viking age 
Table 1. Summarised similarities and differences of complexity between Viking Age society and Hawaiian pre-contact society

\begin{tabular}{|c|c|}
\hline \multicolumn{2}{|c|}{ Similarities } \\
\hline Germanic Iron Age/Viking Age (AD 400-ca. 1000) & Hawaiian pre-contact society (AD 1000-1790) \\
\hline 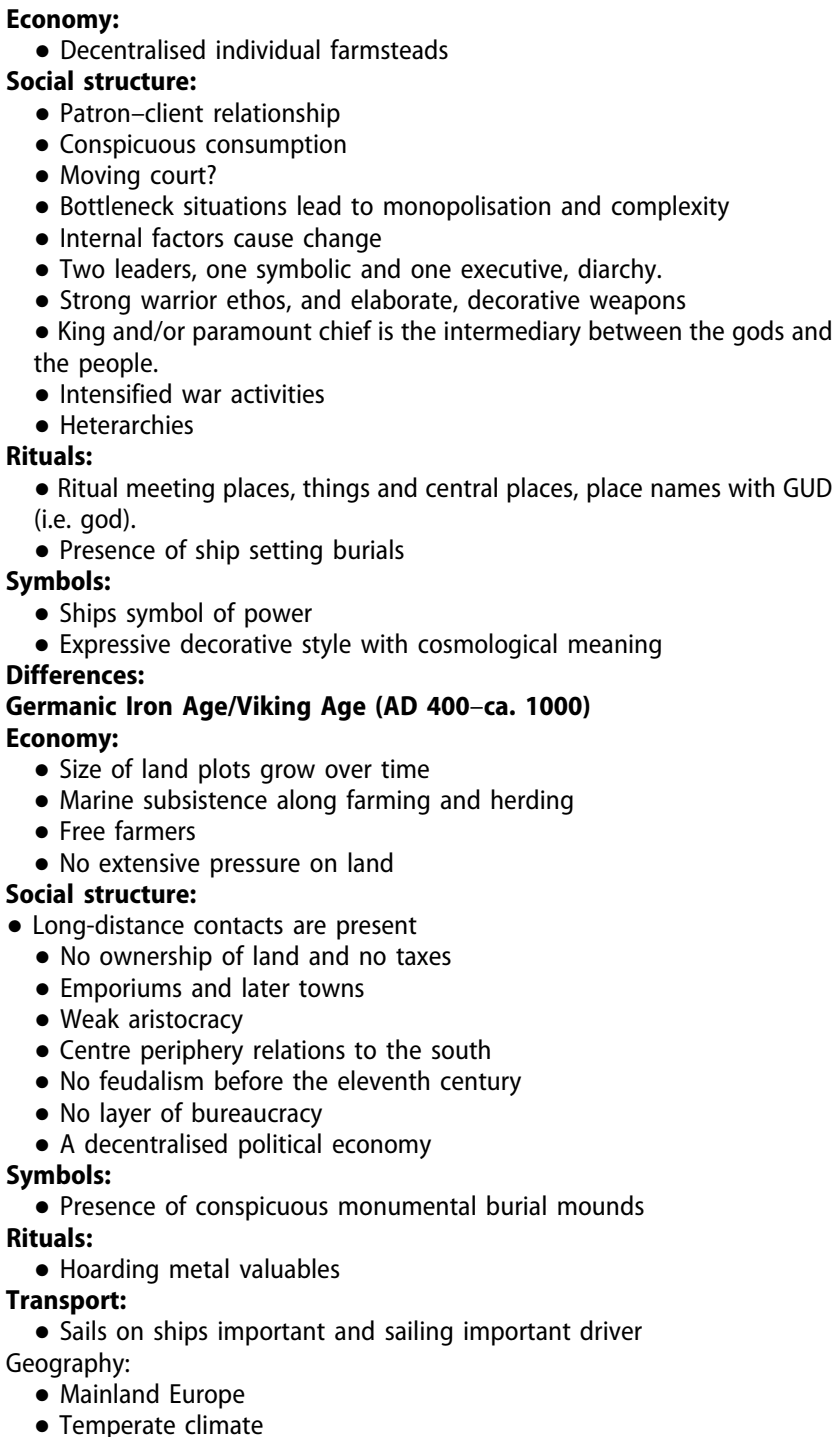 & $\begin{array}{l}\text { Economy: } \\
\text { - Decentralised individual farmsteads } \\
\text { Social structure: } \\
\text { - Patron-client relationship } \\
\text { - Conspicuous consumption } \\
\text { - Moving court } \\
\text { - Bottleneck situations lead to monopolisation and complexity } \\
\text { - Internal factors cause change } \\
\text { - Two leaders, one symbolic and one executive, diarchy } \\
\text { - Strong warrior ethos, and elaborate, decorative weapons } \\
\text { - King and/or paramount chief is the intermediary between the gods and } \\
\text { the people. } \\
\text { - Intensified war activities } \\
\text { - Heterarchies } \\
\text { Rituals: } \\
\text { - Ritual meeting places - platforms } \\
\text { - Possible ship setting burials in some instances } \\
\text { Symbols: } \\
\text { - Canoes symbol of power } \\
\text { - Expressive decorative style with cosmological meaning } \\
\text { Hawaiian pre-contact society (AD 1000-1790) } \\
\text { Economy: } \\
\text { - Size of land plots diminish over time } \\
\text { - Terrestrial economy along farming and herding } \\
\text { - Farmers become subjected in late phase } \\
\text { - Pressure on land } \\
\text { Social Structure: } \\
\text { - Long - distance contacts are not present } \\
\text { - Ownership of land and taxes } \\
\text { - No emporiums and towns } \\
\text { - Strong chiefs over time } \\
\text { - Peer polity pressure between islands } \\
\text { - Feudalism } \\
\text { - Several layers of bureaucracy } \\
\text { - A gradual centralised political economy } \\
\text { Symbols: } \\
\text { - No presence of conspicuous monumental burials } \\
\text { Rituals: } \\
\text { Transport: } \\
\text { - Sails on canoes not important anymore (in late phase) } \\
\text { Geography: } \\
\text { - Pacific Ocean } \\
\text { - Tropical climate }\end{array}$ \\
\hline
\end{tabular}

called thegns and earls, appear, while in Hawaii the konohiki, an individual specialising in creating and collecting surplus, developed. Patron-client relationships, as defined by Sigurdsson (2008. p. 24), are also common to both. Earle and Spriggs (2015, p. 525) called Hawaiian society 'feudal'. In both places, bottleneck situations were created, making monopoly of power possible. In Hawaii it was most likely access to land and prestige goods that caused it. In Scandinavia, it was access to prestigious items, exotics and maybe infanticide and bride wealth (Wicker 1998). Infanticide instigated bands of 'surplus' young men in need of bride-wealth to seek riches and fortune in raiding (Burström 1993, Barrett 2008, p. 680, see also Price 2016).
In both places, the king/paramount most likely was peripatetic. In addition, there were possibly stranger kings in the late phase in both places (Dobat 2009, Hommon 2013). In both places, a heterarchy was most likely present. Heterarchies are where: 'forms of order exist that are not exclusively hierarchical and... interactive elements in complex systems need not be permanently ranked relative to one another' (Crumley 1995, p. 3).

Also, elaborate rituals are present in both places. Initially, it was a primus inter pares, but later the king, and even later yet an appointed priest, who conducted the major rituals. In Hawaii and South Scandinavia the king and/or paramount chief was the intermediary between the gods and the people. 
In terms of prestige goods, there was a strong warrior ethos, as well as elaborate chiefly weapons and functional warrior costumes. In terms of symbols, expressive decorative styles with cosmological meanings are present in both Viking society and in Hawaii. Among the Viking warriors, the sword had high prestige. In Hawaii, clubs and adzes and the spiritual armour of feathered helmets and cloaks were prestigious. In addition, conspicuous consumption by elites is a common element.

In terms of transportation, seafaring was the dominant method of communication. Possessing a large double canoe in Hawaii was as prestigious as having a ship in Scandinavia. The voyaging canoe in Hawaii, as with the Viking ship, was a means for magnates to grasp power by warfare.

\section{Dissimilarities}

In terms of transportation, Sails and sail technology being a techno-deterministic, mono-causal mover for change do not seem likely in a comparative approach, let alone in a long-term perspective, though sailing playing a role in creating a maritime social structure has been presented as a driver in particular cases (Glørstad and Melheim, P. 98-100, Kristiansen 2016, Price 2016). In Hawaii, the presence of sails was not important. Seen in a European context, sailing but not sails were important long before the Viking Age. For example, the AngloSaxons arrived in England in large numbers in the fifth century $\mathrm{AD}$, well before the earliest clear evidence for the use of sails in Northern Europe (Figure 4), leaving a larger genetic impact on the present English population than the Vikings (Leslie et al. 2015, p. 313). This suggests that the cause for the beginning of the kingdoms of the Viking Age must be found in other internal, multi-causal and social factors (see also Näsman 2012, Barrett 2008).

International contacts and exchange were dominant in and before the Viking Age. The emphasis was on commercial ports of trade and later emporia and towns in a centre periphery perspective. This is not the case in Hawaii. This indicates that a peer-polity interaction model is more adequate for explaining the development of stratified societies in Hawaii (Renfrew and Cherry 1986), where towns were not a prime mover (see Näsman 2006, p. 224). International contacts thus are not always essential for the development of complexity.

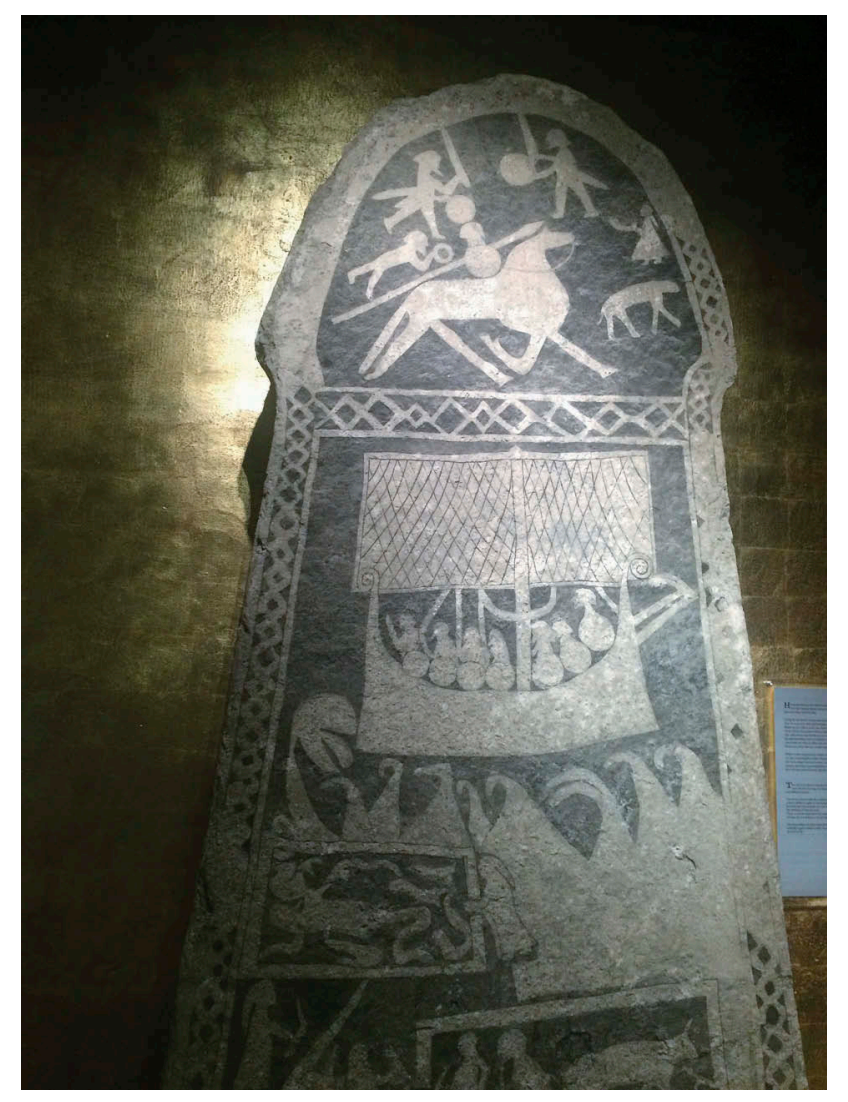

Figure 4. Details from the Hunninge stone from Gotland, Sweden, showing the presence of sails before the Viking Age proper. Although debated this stone dates most likely to the early eighth century. The figures are probably mythological, illustrating the journey by ship by a fallen warrior to the Valhalla of Odin. There a woman with a drinking horn, probably a Valkyrie welcomes the warrior. Under the ship, we probably have the myth about Sigurd Fafnarsbane where his brother-inlaw Gunnar is thrown in the doom of the snakes to die. On show in Gotland Museum (Photo: Mads Ravn).

A large empire to the south, on the other hand, must have been essential for the pressure towards centrality and its collapse towards decentrality in Scandinavia (Wickham 2005, p. 369).

The tradition of prestige goods, especially hoarding metal valuables in the landscape, is not present in Hawaii, where public rituals and prestigious artefacts and canoes were used as a means of conspicuous consumption. In terms of symbols, there are no monumental burial mounds in Hawaii. Either the Hawaiians buried their dead in caves, sand dunes or the sea; high ranked chiefs were often given hidden burials to avoid the use of their bones as artefacts by those seeking to gain some of the power they had in life.

A major difference to Hawaii is in terms of subsistence and economy. In Hawaiian society access to land 
was much more restricted than in Germanic and early Viking Age society (Wickham 2005, p. 379). It also seems that there was less pressure on land in South Scandinavia than in Hawaii. We see further subdivisions over time within the Hawaiian field systems (Ladefoged and Graves 2006, p. 270) as pressure on land increased (Hommon 2013, p. 232). Indeed the relatively open access to land in Scandinavia, where the farm plots increased in size over time, stands in contrast to Hawaiian society. In the late Germanic Iron Age and early Viking Age society there was a gradual concentration of land where variation in plot size suggests that some individuals were much wealthier than others. This interpretation may be comparable with the concentration of large landowners in Hawaii, but it appears differently in the archaeology and further study is needed (see Holst 2010, p. 169, Løvschal 2017, Vogt 2017). Finally, there is no development of central places with rich metals, towns, numerous monuments and nucleated settlements in Hawaii.

\section{Discussion - a balanced comparative archaeology}

The purpose here has been to establish a framework for a more balanced, comparative archaeology in order to understand the development of early complex societies, using two different complex societies as analogy. I argue that such an approach can be productive if we want to understand both the comparative cultures' prerequisites and developments in a long-term perspective (see also Glørstad and Melheim 2016). By looking at similar and different processes over time and across a wider area, we can better isolate how important geographic, cultural, technological, ideological and ecological factors were for the development and change in individual places.

I shall not discuss in detail a volcanic eruption in ca. $\mathrm{AD} 536$, which has been seen by some as leading to hard times and eventually the conversion to a Viking Society (Löwenborg 2012). I consider it a mono-causal, external, and thus a non-explanatory factor (see also comments by Näsman 2012, Gräslund and Price 2012), though it need mentioning, as it is comparable to Hommon's external, hard times hypothesis for the development of complexity in Hawaii.

I prefer the hypothesis that a social bottleneck developed as a result of the selective infanticide of female newborns, leading to too few women (Wicker 1998). This instigated bands of 'surplus' young men in need of bride-wealth who sought riches and fortune in raiding (Barrett 2008, p. 680). This is an internally caused bottleneck. Additionally, an economic bottleneck developed, because access to land was gradually monopolised by stronger magnates who waged war between polities in Scandinavia. Ships made it possible to rally young men that could gain wealth (Price 2016). This happened before the Viking Age. Whatever factor was more important; it was internal social causes and could have meant that Viking Age society also reached its limits for traditional agriculture as people did in Hawaii due to the limited amount of land on these remote islands.

In Europe there was room for emigrating and raiding, which was only the case in Hawaii between a limited numbers of islands. Hence, the Vikings eventually settled in Ireland, Scotland and England in the late ninth century. In Hawaii, land pressure led to wars, which led to centralised state formation that, in terms of complexity, surpasses the Scandinavian Viking society.

\section{Are the Viking kingdoms states?}

The comparative approach, adopted in the discussion above, suggests that the Viking Age kingdoms of South Scandinavia were quite different, much less stratified, and much more decentralised than the Hawaiian state. Viking society therefore cannot be called a state. The absence of an advanced bureaucracy and the lack of evidence for the collection of taxes and ownership of land in the Viking Age kingdoms are particularly problematic. Following the definition of Hommon, Viking Age society may be called an advanced chiefdom rather than an archaic state (Hommon 2013, p. 118-122). A state, as defined by Hommon, did not appear in Scandinavia until much later, more likely between the tenth to fourteenth centuries (see Dobat 2009, Roesdahl 2016, p. 175, Bagge 1999). According to Wickham the kingdom societies in South Scandinavia should be called prestate systems (Wickham 2005, p. 56), peasant mode or ranked societies $(2005$, p. 304). Indeed, it is a question whether the term heterarchy (Crumley 1995, p. 3) is more appropriate to the Scandinavian later Germanic Iron Age and Viking Age, as also suggested indirectly by Holst (2014, p. 181). 


\section{Conclusions - comparative archaeology as an exploratory prism}

This comparative sketch has presented a 'lens' though which to view the formation of the Viking Age Kingdoms and the Hawaiian state anew. The aim has been to discuss the usefulness of a comparative archaeology without making yet another neoevolutionist stereotype. One difference from a neoevolutionist perspective is the focus on differences instead of similarities (Smith 2012, Smith and Peregrine 2012, p. 4). Also, in that perspective, I emphasise a renewed focus on analogy.

The aim here has not been to make the Vikings into Hawaiians as with typical formal analogies. Rather, by playing these two complex societies off against each other, using them not as mirrors, as suggested by Glørstad and Melheim (2016), but more precisely as dispersive prisms, refracting the light spectre of reflecting images into details, we learn more about the development of complex societies in general and the two compared societies in particular. According to Smith (2012), and Smith and Peregrine (2012, p. 7), it may be called an intensive comparative method, where I expand the comparative frame with a focus on analogy and a perspective that focuses on diverse hierarchical modes (Feinman 2012, p. 29) and heterarchies (Crumley 1995). The relationship between these two latter terms may be the next level to explore, as indeed the relationship between hierarchy and power as problematised by Iteanu (2009, p. 343).

What is common between Earle and Spriggs and Wickham but not Hommon is a materialist focus and a focus on internal factors, defined at factors happening within society, as opposed to external influences such a for example natural disasters. Indeed, Wickham writes (Wickham 2005, p. 831): 'social change is overwhelmingly the result of internal factors, not external influences, which has been one of the arguments most often made in this book. Such a recognition is also the best protection against teleological interpretations of history, which are always misleading'.

In contrast, Hommon sees hard times as a defining factor, a situation developed from population pressure and intensification of agriculture.

A common factor in this study is the ability for aspiring leaders to create bottlenecks, as Earle and Spriggs also suggest. These are created in various ways, depending on different geographies, ecologies, social structures and ideologies in combination in each place.

The overall preliminary conclusion of a comparative approach in this paper is that there are several roads to complexity. Bottleneck situations appear differently in different regions leading to similar, though not identical results. By comparing different trajectories we may better comprehend specific defining patterns for the development and maintenance of past, present and future complex societies (Turchin et al. 2013). In this way, the analogical approach presented here is much more an epistemological exercise to think with, than a theoretical explanation of how complex societies and states came about.

\section{Acknowledgments}

This work was supported by the Kon-Tiki Museum and Vejle Museums. I am grateful to Assistant Professor Mette Løvschal and Professor Matthew Spriggs and Dr Sean Denham for commenting on earlier versions of this paper. Finally, I thank two anonymous peer reviewers.

\section{ORCID}

Mads Ravn (D) http://orcid.org/0000-0002-5657-771X

\section{References}

Bagge, S., 1999. The structure of the political factions in the internal struggles of the Scandinavian countries during the high middle ages. Scandinavian Journal of History, 24, 299-320. doi:10.1080/03468759950115719

Barrett, J.H., 2008. What caused the Viking Age ? Antiquity, 82, 671-685. doi:10.1017/S0003598X00097301

Beaglehole, J.C., ed., 1967. The voyage of the resolution and discovery 1776-1780. The journals of captain james cook on his voyages of discovery. Vols. 3 , in 2 parts. Cambridge: Cambridge University Press.

Braudel, F., 1980. On History. Chicago: The University of Chicago Press.

Burström, M., 1993. Silver as bridewealth, an interpretation of Viking Age silver hoards on Gotland, Sweden. Current Swedish Archaeology, 1, 33-37.

Champion, T.C., ed., 2005. Centre and periphery. Comparative studies in archaeology. In: One world archaeology 11. London and New York: Routledge.

Christensen, T., 2015. Lejre bag myten. De arkoologiske udgravninger. Denmark: Jysk Arkæologisk Selskabs Skrifter 87: Højbjerg. 
Crumley, C.L., 1995. Hetearchy and the analysis of complex societies. In: R.M. Ehrenreich, C.L. Crumley, and J.E. Levy, eds. Heterarchy and the analysis of complex societies. Washington, D.C.: Archaeological papers of the American Anthropological Association, Vol. 6, 1-5.

Dobat, A.S., 2009. The state and the strangers: the role of external forces in a process of state formation in Viking Age South Scandinavia (c. AD 900-1050). Viking and Medieval Scandinavia, 5, 65-104. doi:10.1484/J.VMS.1.100674

Drennan, R.D., et al. 2012. Comparative archaeology. A commitment to understanding variation. In: M.E. Smith, ed. The comparative archaeology of complex societies. Cambridge: Cambridge University Press, 1-3.

Earle, T. and Spriggs, M., 2015. Political economy in prehistory. A marxist approach to pacific sequences. Current Anthropology, 56 (4), 515-544. doi:10.1086/682284

Feinman, G.M., 2012. Comparative frames for the diachronic analysis of complex societies. In: M.E. Smith, ed. The comparative archaeology of complex societies. Cambridge: Cambridge University Press, 21-43.

Gillespie, S.D., 2000. Levi Strauss: maison and Société à Maisons. In: R.A. Joyce and S.D. Gillespie, eds. Beyond kinship. social and material reproduction in house societies. Philadelphia: Penn, University of Pennsylvania Press, 22-52.

Glørstad, Z.T. and Melheim, L., 2016. Past mirrors: thycydides, Sahlins and the Bronze and Viking Ages. In: Z.T. Glørstad, H. Glørstad, and L. Melheim, ed. Comparative perspectives on past colonisation, maritime interaction and cultural integration. Sheffield: Equinox, 87-108.

Goldman, I., 1970. Ancient polynesian society. Chicago: University of Chicago Press.

Grabowski, R., 2014. Identification and delineation of settlement space functions in the South Scandinavian Iron age: theoretical perspectives and practical approaches. Journal of Archaeology and History, 12, 3-57.

Gräslund, B. and Price, N., 2012. Twilight of the gods? The 'dust veil event' of $\mathrm{AD} 536$ in critical perspective. Antiquity, 86 (332), 428-443. doi:10.1017/S0003598X00062852

Gregory of Tours., 1974. Historia Francorum. London: Penguin books.

Hawking, S.W., 1974. Black hole explosions. Nature, 248, 3031. doi:10.1038/248030a0

Hedeager, L., 1992. Iron age societies. From tribe to state in Northern Europe. 500 BC to AD 700. Oxford: Blackwell.

Holst, M.K., 2010. Inconstancy and stability - large and small farmsteads in the village of Nørre Snede (Central Jutland) in the first millennium AD. Siedlungs- Und Küstenforschung Im Südlichen Nordseegebiet, 33, 155-179.

Holst, M.K., 2014. Warrior aristocracy and village community. In: E. Stidsing, K.H. Nielsen, and R. Fiedel, eds. Wealth and complexity. Economically specialised sites in late iron age Denmark. Aarhus: Aarhus University Press, 179-198.

Hommon, R., 2013. The ancient Hawaiian state: origins of a political society. Oxford/New York: Oxford University Press.
Iteanu, A., 2009. Hierarchy and power. A comparative attempt under asymmetrical lines. In: K.M. Rio and O.H. Smedal, eds. Hierarchy. persistence and transformation in social formation. New York, Oxford: Berghahn Books, 331-348.

Jessen, M.D. and Holst, M.K., 2008. Om huse og slægtskab i Skandinaviens yngre jernalder. Jordens Folk, 3, 44-51.

Jørgensen, L., 2010. Gudme and Tissø. Two magnate's complexes in Denmark from the 3rd to 11th Cent. AD. In: B. Ludowici, ed. Trade and communication networks of the first millennium $A D$ in the northern part of central Europe: central places, beach markets, landing places and trading centres. Hannover: Neue Studien zur Sachsenforschung, Vol. 1, 273-286.

Kirch, P.V., 2000a. Temples as "Holy houses": the tranformation of ritual architecture in traditional Polynesian societies. In: R.A. Joyce and S.D. Gillespie, eds. Beyond kinship. Social and material reproduction in house societies. Philadelphia: Penn, University of Pennsylvania Press, 103-114.

Kirch, P.V., 2000b. On the road of the winds. An archaeological history of the Pacific Islands before European contact. Berkeley: University of California Press.

Kristiansen, K., 2016. Bronze Age Vikings? A comparative analysis of deep historical structures and their dynamics. In: Z.T. Glørstad, H. Glørstad, and L. Melheim, ed. Comparative perspectives on past colonisation, maritime interaction and cultural integration. Sheffield, Bristol: Equinox, 177-186.

Kristiansen, K., 2017. The nature of archaeological knowledge and its ontological turns. Norwegian Archaeological Review, 50 (2), 1-4. doi:10.1080/ 00293652.2017.1372802

Ladefoged, T. and Graves, M., 2006. The formation of Hawaiian territories. In: I. Lilley, ed. Archaeology of Oceania, Australia and the Pacific Islands. Oxford: Blackwell Publishing, 259-283.

Leslie, S., et al., 2015. The fine scale genetic structure of the British population. Nature, 519, 309-314. doi:10.1038/ nature 14230

Ljungqvist, J. and Frölund, P., 2015. Gamla Uppsala - the emergence of a centre and a magnate complex. Journal of Archaeology and Ancient History, 16, 1-29.

Løvschal, M., 2017. Emerging boundaries. Social embedment of landscape and settlement divisions in Northwestern Europe during the first Millennium BC. Current Anthropology, 55, 725-750.

Löwenborg, D., 2012. An Iron Age Shock Doctrine - did the AD 536-7 event trigger large-scale social changes in the Mälaren valley area? Journal of Archaeology and Ancient History, 4, 1-29.

Näsman, U., 2006. Danerne og det danske kongeriges opkomst. Om forskningsprogrammet 'fra stamme til stat i Danmark'. Kuml, 205-237.

Näsman, U., 2012. Comments on "An iron age shock doctrine: the 536-37 event as a trigger of large-scale social change in the Mälaren valley area” by Daniel Löwenborg.? 
Journal of Archaeology and Ancient History, (4), 5-17. Available from: http://www.arkeologi.uu.se/digitalAssets/ 484/c_484746-1_3-k_log_jaah2012_4_lowenborg.pdf

Price, N., 2016. Pirates of the North Sea? The Viking ship as political space. In: Z.T. Glørstad, H. Glørstad, and L. Melheim., eds. Comparative perspectives on past colonisation, maritime interaction and cultural integration. Sheffield, Bristol: Equinox, 149-176.

Ravn, M., 1993. Analogy in Danish Prehistoric Studies. Norwegian Archaeological Review, Vol.26 (2), 59-75. doi:10.1080/00293652.1993.9965559

Ravn, M., 2003. Death ritual and germanic social structure. (ca. AD 200-600). Oxford: BAR international series 1164.

Ravn, M., 2011. Ethnographic analogy from the Pacific: just as analogical as any other analogy. World Archaeology, 43 (4), 716-725. doi:10.1080/00438243.2011.624781

Ravn, M. et al. in prep. Erritsø - A fortified early viking age manor near Lillebcelt. New investigations and research perspectives. To be published in proceedings from the 36th interdisciplinary Sachsensymposium.

Renfrew, C. and Cherry, J., eds., 1986. Peer polity interaction and socio-political change. Cambridge: Cambridge University Press.

Roesdahl, E. 2016. The unification process of the Danish Kingdom -and the Danish Husebyer and their owners. In: L.E. Christensen, T. Lemm, and A. Pedersen, Ed. Husebyer - status quo, open questions and perspectives. Vol. 20:3 Jelling Series, Copenhagen: Publications from the National Museum. Studies in Archaeology \& History, $175-182$.

Roscoe, P., 2009. On the 'Pacification' of the European Neolithic: ethnographic analogy and the neglect of history. World Archaeology, 41, 578-588. doi:10.1080/ 00438240903345621

Rousseaux, G., 2013. The basics of water waves theory for analogue gravity. In: D. Faccio, et al., ed. Lecture Notes in Physics. Analogue gravity phenomenology: analogue spacetimes and horizons from theory experiment. Vol. 870. Switzerland: Springer, Cham, 81-107.

Sahlins, M., 1958. Social stratification in Polynesia. Seattle: American Ethnological society.

Sahlins, M., 1985. Islands of History. Chicago: University of Chicago Press.

Sand, C., 2002. Melanesian tribes vs. Polynesian Chiefdoms: recent archaeological assessment of a classic model of sociopolitical types in Oceania. Asian Perspectives, 41, 2,284-296. doi:10.1353/asi.2003.0010

Sigurdsson, J.V., 2008. Det norrøne samfunnet. Vikingen, kongen, erkebiskoppen og bonden. Oslo: Pax.

Smith, M.E., ed., 2012. The comparative archaeology of complex societies. Cambridge: Cambridge University Press.

Smith, M.E. and Peregrine, P., 2012. Approaches to comparative analysis in archaeology. In: M.E. Smith, ed. The comparative archaeology of complex societies. Cambridge: Cambridge University Press, 4-20.
Sørensen, T.F., 2017. The two cultures and a world apart: archaeology and science at new crossroads. Norwegian Archaeological Review, 50 (2), 101-105. doi:10.1080/ 00293652.2017.1367031

Spriggs, M., 2008. Ethnographic parallels and the Denial of History. World Archaeology, 40 (4), 538-552. doi:10.1080/ 00438240802453161

Spriggs, M., et al. 2016. Lapita and the Linearbandkeramik: what can a comparative approach tell us about either? In: L. Armkreutz, ed. Something out of the ordinary? Interpreting diversity in the early neolithic linearbandkeramik and beyond. Newcastle upon Tyne: Cambridge Scholars Publishing, 481-503.

Sterrett, S.G., 1998. Sounds like light: einstein's special theory of relativity and Mach's work in acoustics and aerodynamics. Studies in History and Philosophy of Modern Physics, 29 (1), 1-35. doi:10.1016/S1355-2198 (97)00027-0

Sterrett, S.G., 2017. Experimentation on analogue models. In: L. Magnani and T. Belotti, eds. Springer handbook on model-based science, chapter 39. Switzerland: Springer International Publishing, 855-876.

Turchin, P., et al. 2013. War, space, and the evolution of old world complex societies. Proceedings of the National Academy of Sciences, 110 (41), 16385-16389. doi:10.1073/ pnas. 1308825110

Visser, M., 2003. Essential and inessential features of Hawking radiation. International Journal of Modern Physics, (12), 649-661. doi:10.1142/S0218271803003190

Vogt, H., 2017. From tribute to taxpaying: the changes in the understanding of private property in Denmark circa 1000-1250. Danish Journal of Archaeology, [Online], 1-8. doi:10.1080/21662282.2017.1323993 [Accessed 14th November 2017].

Wallerstein, I., 1974. The modern world system: capitalist agriculture and the origins of the European world-economy in the sixteenth century. New York: Academic Press.

Wicker, N.L., 1998. Selective female infanticide as partial explanation for the dearth of women in Viking Age Scandinavia. In: G. Hallsal, ed. Violence and society in early medieval West. Woodbridge: The Boydell press, 205-221.

Wickham, C., 2005. Framing the early middle ages. Europe and the Mediterranean, 400-800. Oxford: Oxford University Press.

Wylie, A., 1982. An analogy by any other name is just as analogical: a commentary on the Gould-Watson dialogue. Journal of Anthropological Archaeology, (1), 382-401. doi:10.1016/0278-4165(82)90003-4

Wylie, A., 1985. The reaction against analogy. Advances in Archaeological Method and Theory, (8), 63-111.

Wylie, A., 1989. Archaeological cables and tacking: the implications of practice for bernstein's 'options beyond objectivism and relativism,' . Philosophy of the Social Sciences, (19), 1-18. doi:10.1177/004839318901900101 